North America, led by the United States,

Breeding Trait Priorities of the Blueberry Industry in the United States and Canada

\author{
R. Karina Gallardo \\ School of Economic Sciences, Puyallup Research and Extension Center, \\ Washington State University, 2606 West Pioneer Street, Puyallup, WA 98371
}

Qi Zhang

School of Economic Sciences, Washington State University, P.O. Box 646210, Pullman, WA 99164

Michael Dossett

B.C. Berry Cultivar Development, Inc., C/O Agriculture and Agri-Food Canada, Agassiz Research and Development Centre, 6947 Highway \#7, Agassiz, BC V0M 1A0, Canada

James J. Polashock

USDA-ARS, 125A Lake Oswego Road, Chatsworth, NJ 08019

Cesar Rodriguez-Saona and Nicholi Vorsa

P. E. Marucci Blueberry and Cranberry Research and Extension Center, Rutgers University, 125A Lake Oswego Road, Chatsworth, NJ 08019

\section{Patrick P. Edger}

Department of Horticulture, Michigan State University, 1066 Bogue Street, East Lansing, MI 48824

\section{Hamid Ashrafi}

Department of Horticultural Science, North Carolina State University, 2721 Founders Drive, Raleigh, NC 27695

Ebrahiem Babiker

Thad Cochran Southern Horticultural Laboratory, USDA-ARS, 810 HWY 26 West, Poplarville, MS 39470

\section{Chad E. Finn}

Horticultural Crops Research Unit, USDA-ARS, 3420 NW Orchard Avenue, Corvallis, OR 97330

\section{Massimo Iorizzo ${ }^{1}$}

Plants for Human Health Institute and Department of Horticultural Science, North Carolina State University, 600 Laureate Way, Kannapolis, NC 28081

Additional index words. berry breeding, industry priorities survey, cultivars

Abstract. Developing new blueberry cultivars requires plant breeders to be aware of current and emerging needs throughout the supply chain, from producer to consumer. Because breeding perennial crop plants (such as blueberry) is time- and resourceintensive, understanding and targeting priority traits is critical to enhancing the efficiency of breeding programs. This study assesses blueberry industry breeding priorities for fruit and plant quality traits based on a survey conducted at commodity group meetings across nine U.S. states and in British Columbia (Canada) between Nov. 2016 and Mar. 2017. In general, industry responses signaled that the most important trait cluster was fruit quality including the firmness, flavor, and shelf life. Fruit quality traits affect price premiums received by producers; influence consumer's preferences; and have the potential to increase the feasibility of mechanical harvesting, all critical to the economic viability of the industry. There were differences across regions in the relative importance assigned to traits for disease resistance, arthropod resistance, and tolerance to abiotic stresses. Our findings will be useful to researchers seeking solutions for challenges to the North American blueberry industry including development of new cultivars with improved traits using accelerated DNA-based selection strategies. is the world's largest producer of blueberries. Driven in part by the recognition of health benefits associated with blueberry consumption (Forney and Kalt, 2011), world production grew 35\% from 2006 to 2014 (U.N. Food and Agriculture Organization, 2017) positively affecting the economy of blueberry-producing regions in the United States (Sullivan and Schilling, 2008). In 2016, the top seven blueberry-producing states in the United States were Washington $(54,470 \mathrm{t})$, Oregon $(52,690$ t), Michigan (45,370 t), Georgia (30,400 t), California $(24,560 \mathrm{t})$, North Carolina $(20,900$ t), and New Jersey $(16,111 \mathrm{t}$ ) (Brazelton et al., 2017). In the United States, $52 \%$ of blueberries were used fresh and $48 \%$ were processed (Brazelton et al., 2017).

Development of new cultivars has played and will continue to play a major role in the growth of the blueberry market in North America and worldwide. In the last two decades, breeding programs have developed improved cultivars that have supported the expansion of blueberry production into new growing areas, such as low-chill regions and the southern hemisphere. In the latest Global Blueberry Statistics Intelligence Report, Brazelton et al. (2017) suggested that-after a decade of significant production expansion and growth - the blueberry market in North America has matured and the industry was becoming more selective and quality-driven. In this new market phase, genetic gains will be a key factor to sustain the growth of the blueberry industry.

This research emerged from a planning grant (2016-51181-25401) funded by the U.S. Department of Agriculture, National Institute of Food and Agriculture-Specialty Crop Research Initiative to examine the current and future needs of research and extension for cranberry and blueberry. The overall goal of this project was to begin planning efforts to advance the genetic, genomic, and phenotypic resources available for blueberry and cranberry and develop genomic tools to guide and accelerate the development of improved cultivars. This study identifies breeding trait priorities in the U.S. and Canadian highbush blueberry industries.

The primary focus of blueberry breeding programs in the United States is to improve two types of highbush blueberry cultivars (Vaccinium corymbosum, $2 n=4 x=48$ ) termed northern highbush blueberry (NHB) and southern highbush blueberry (SHB), the rabbiteye (RY) cultivars (Vaccinium virgatum, $2 n=6 x=72$ ) and their interspecific hybrids (Hancock et al., 2008). Of these, NHB and SHB cultivars are the most common types of blueberries cultivated throughout the world. The breeding of highbush blueberries is a long and tedious process. Traditional approaches can take from 9 to 20 years from the original cross, selection, and comparison with existing cultivars to cultivar release. In the last 10 years, marker-assisted breeding has become a costeffective strategy for crop improvement 
programs by increasing selection efficiency and shortening the time it takes to develop a cultivar (Yang et al., 2015). However, the application of this technology requires extensive training, knowledge, and significant investments to generate genomic resources. For these reasons, it is critical to focus on genetic traits of maximum value (Alpuerto et al., 2009; Gallardo et al., 2012; Luby and Shaw, 2001; Yue et al., 2012). Determining trait priorities is difficult because trait relevance depends on what sector of the supply chain is involved in the decision-making process. Only a few horticultural studies have investigated trait priorities for plant breeding programs (Gallardo et al., 2012; Yue et al., 2012). In blueberry, a consumer preference study assessed the impact of 36 specific blueberry sensory and psychological traits on consumer preferences (Gilbert et al., 2014). Most research on blueberry breeding traits deemed important to the industry focuses on traits associated with climate and soil adaptation. For instance, tolerance to high soil $\mathrm{pH}$ and mineral soils, chilling requirement, and cold-hardiness have been identified as important traits for expanding the acreage of blueberry in nontraditional production areas in the United States (Hancock et al., 2008). Early bloom, ripening interval, and frost tolerance are considered target traits to expand the harvest season and cover market windows where production is low and price is at a premium (Hancock et al., 2008). Because of financial and labor shortage concerns, producers are increasingly interested in using machine harvesting to harvest blueberries to be sold in the fresh market (Takeda et al., 2008). Firm fruit, suitable bush architecture, easy detachment

Received for publication 6 Feb. 2018. Accepted for publication 16 Mar. 2018.

Funding for this study was provided by the USDA-NIFA Specialty Crop Research Initiative, Award Number 2016-51181-25401.

We gratefully acknowledge the support and assistance of Parichat Klingthong, Harald Scherm, William O. Cline, Megan Bame, Hamed Bostan, Yunyang Zhao, Nahla V. Bassil, Kim E. Hummer, Changying Li, Mary Ann Lila, Penelope PerkinsVeazie and Lisa J. Rowland, Gary Pavlis, Renee Allen, Yang Wei Qiang, Jeffrey G. Williamson, and Bill Baisley. We acknowledge the following organizations for supporting the planning grant and for their help in coordinating the distribution of the survey: Massachusetts Cultivated Blueberry Growers Association; Washington Blueberry Commission; Georgia Blueberry Growers Association; Florida Blueberry Growers Association; Oregon Blueberry Commission; Lower Mainland Horticulture Improvement Association; North Carolina Blueberry Council, Inc.; Gulf South Blueberry Growers Association; New Jersey Blueberry and Cranberry Research Council; British Columbia Blueberry Council; Berry Blue LLC; California Blueberry Commission; Dole Nutrition Institute; Driscoll's, Inc.; Fall Creek Farm \& Nursery, Inc.

${ }^{1}$ Corresponding author. E-mail: miorizz@ncsu. edu.

This is an open access article distributed under the CC BY-NC-ND license (http://creativecommons. org/licenses/by-nc-nd/4.0/). of mature berries vs. immature berries, loose fruit clusters, small stem scar, and a concentrated ripening period have been identified as breeding goals to develop blueberry cultivars suitable for machine harvest (Olmstead and Finn, 2014). These previous studies provide some insights about trait preferences, but a systematic investigation of the blueberry industry's trait priorities has not been conducted. Such information would assist in breeders' selection of traits and improve the efficiency of breeding programs.

The goal of this study was to survey and rank the blueberry industry's priorities for blueberry plant and fruit traits. A secondary objective was to compare these results with published reports on consumer preferences and on cultivar adoption in the industry. The results for the most important traits are discussed in the context of current scientific knowledge based on published phenotyping and genetic studies in blueberry. This will provide a framework to identify the objectives that breeders and allied scientists need to consider when designing research projects that can facilitate the selection of new cultivars with superior traits deemed important to the industry.

\section{Methods}

Survey design. Research priorities from seven state and provincial blueberry commodity groups (Michigan, Washington, North Carolina, Georgia, California, Oregon, and British Columbia) and two national or regional research organizations (USDA-ARS National Clonal Germplasm Repository Small Fruit Crop Germplasm Committee and the USDA-ARS Northwest Center for Small Fruits Research) were extracted from recent research grant proposal requests and research priority recommendations and grouped based on the production-related needs (e.g., pest and disease related needs) to identify clusters of fruit and plant traits that could directly or indirectly provide benefits to the blueberry industry. Hereafter, the term blueberry industry refers to nurseries, producers, packers, processors, breeders, and nonbreeder researchers. Six trait clusters were derived heuristically from this list, including 1) fruit quality, 2) disease resistance, 3) arthropod pest resistance (note that the survey used "insect pest resistance" to refer to arthropod pest resistance, which we use hereafter, because some pests are not true insects), 4) plant stress tolerance, 5) other plant traits, and 6) machine harvestability. Each cluster of traits included an "other trait" option in case we missed an important trait in the list of traits presented to the respondents. The survey form, which was approved by the Institutional Review Board, Washington State University IRB \#15708, is available at the Vaccinium Planning Project web page (https://pgnglab.plantsforhumanhealth. ncsu.edu/vaccinium-project/survey/).

The traits included in the fruit quality cluster were color, crispness, firmness, flavor, nutritional benefit, shape/appearance, shelf life, size, small dry stem scar, sweetness, and "other fruit quality traits." Disease resistance traits included the following: algal stem blotch (Cephaleuros spp.), Alternaria fruit rot (Alternaria tenuissima), anthracnose fruit rot (Colletotrichum fioriniae, syn. Colletotrichum acutatum), bacterial canker (Pseudomonas syringae pv. syringae), bacterial leaf scorch (Xylella fastidiosa), Blueberry scorch virus (B1ScV), blueberry stunt (primarily 'Candidatus Phytoplasma asteris'), Botrytis flower blight and fruit rot (Botrytis cinerea), Exobasidium leaf and fruit spot (Exobasidium maculosum), fungal leaf spots (incited by multiple fungal taxa), rust diseases (Thekopsora minima or Naohidemyces vaccinii), mummy berry (Monilinia vaccinii-corymbosi), Blueberry necrotic ring blotch virus, nematodes (Paratrichodorus spp., Hemicycliophora spp., Xiphinema americanum), Phomopsis canker and twig blight (Phomopsis vaccinii), Phytophthora root rot (Phytophthora cinnamomi), Blueberry shock virus (BlShV), stem blight (incited by multiple species in the Botryosphaeriaceae), and "other diseases." Arthropod pest resistance traits included resistance to spotted wing drosophila (Drosophila suzukii, SWD), blueberry maggot (Rhagoletis mendax), gall midge (Dasineura oxycoccana), flower thrips (primarily Frankliniella spp.), aphids (primarily Aphis sp.), scale insects (primarily Lecanium spp. and Eriococcus spp.), blueberry bud mite (Acalitus vaccinii), brown marmorated stink bug (Halyomorpha halys), cherry fruitworm (Grapholita packardi), sharp-nosed leafhopper (Scaphytopius spp.), cranberry fruit worm (Acrobasis vaccinii), stem borers (multiple species), white grubs (multiple species), stem gall wasp (Hemadas nubilipennis), plum curculio (Conotrachelus nenuphar), and "other insect pests." Plant stress tolerance traits included frost tolerance, tolerance to heat/ ultraviolet (ultraviolet light) damage, drought resistance, winterhardiness, soil type adaptation, and other plant stress traits. Other plant traits included improved yield, ripening time, flowering time, self-pollination, and "other plant traits." Machine harvestability traits included improvements in fruit firmness, uniform ripening, upright growth, loose clusters, flexible canes, monopodial stem, narrow habit, small dry stem scar, and other machine harvestability traits.

The survey asked participants to rank the relative importance of individual traits in each of the six trait clusters (questions 1-6) for a commercially successful blueberry cultivar and then to rank the importance of the six trait clusters (question 7). In each cluster, we asked respondents to rank the first, second, third, etc. most important and the first, second, third, etc. least important trait for a successful cultivar. The ordering number requested (first, second, third, etc.) depended on the number of traits included in each cluster. For example, the fruit quality cluster included 11 traits, hence ranking was requested for the three most and the three least important fruit quality traits. The disease resistance cluster included 19 traits, so we requested respondents to rank the five most and the five least important disease resistance traits. 
Other questions in the survey asked for sociodemographics characteristics of the decision maker and the blueberry operation itself included the following: the respondent's role in the supply chain (e.g., producer, nursery operator, packer, processor, breeder, and nonbreeder scientist); the size of the respondent's blueberry operation, expressed in acres of cultivated area; the number of years the respondent had been involved in the decision-making process of the operation; a list of blueberry cultivars representing the largest cultivated area in the respondent's operation; whether new cultivar(s) had been planted during the last 5 years; and the name of the state in which the largest cultivated area of the operation was located.

Data collection. The blueberry industry survey was conducted at commodity group meetings across nine U.S. states and British Columbia (Canada) between Nov. 2016 and Mar. 2017. The names and locations of the meetings were 1) Massachusetts Cultivated Blueberry Growers Association, Nov. 2016; 2) Lynden Small Fruit Conference, Washington, Dec. 2016; 3) Alma Blueberry Update, Georgia, Jan. 2017; 4) Florida Blueberry Growers Association, Jan. 2017; 5) Oregon Blueberry Conference, Jan. 2017; 6) Lower Mainland Horticulture Improvement Association, British Columbia, Jan. 2017; 7) Great Lakes Expo, Michigan, Jan. 2017; 8) North Carolina Blueberry Open House and Trade Show, Jan. 2017; 9) Gulf South Blueberry Growers Association, Mississippi, Jan. 2017; and 10) Blueberry Open House, New Jersey, Mar. 2017. At each meeting, a scientist or extension educator associated with this study presented the content and the objective of the survey while the audience responded to a paper-based survey. Figure 1 presents the number of completed surveys obtained for each state/province.

Data analysis. To quantify significantly more or less important trait- and industryrelated variables across regions, we analyzed the data using an ordered probit model given that the dependent variable, the ranking of traits, was discrete and ordinal. The survey questions asked to identify the most and least important fruit and plant traits for blueberries, and each trait was assigned a value according to each respondent's ranking. For example, as indicated previously, there were 11 traits in the cluster fruit quality; the first most important trait for each respondent was assigned the number 1 , the second most important trait 2, the third most important trait 3, the third least important trait 9, the second least important trait 10 , and the first least important trait 11 . Traits not identified by the respondent as being among the most important or the least important were considered middle choices and were assigned the median of $1-11$, which is 6 . This method has been used in previous research to elicit the relative level of importance of product attributes (Davis and Gillespie, 2004; Greene and Hensher, 2008; Yue et al., 2013).

The ranking of traits is assumed to depend on underlying utility or measurement of preference derived from the presence of each trait in the blueberry cultivar. The respondents ranked the traits based on a perception of which traits would provide them with the most benefits. Here, the benefits are the present value of all the elements that the respondent considers when ranking the traits according to his/her preferences, which is the same role represented in the utility. This approach follows Lancaster's theory of consumer behavior that states that utility is not derived from a good but from the attribute composition of that good (Lancaster, 1966). In this instance, suppose $U_{i t}$ is the utility that respondent $i$ derives from trait $t$ and $U_{i t}$ can be expressed by $R_{i t}$, which is the ranking assigned by each respondent to each trait. The empirical formulation is

$$
\begin{aligned}
R_{i t}^{n}= & \beta_{0}+\beta_{1 t} \text { Trait }_{i t}+\beta_{2} \text { Producer }_{i} \\
& +\beta_{3} \text { Years }_{i}+\beta_{4} \text { Size }_{i}+\beta_{5} \text { NewCultivar }_{i} \\
& +\beta_{6} \text { Cultivar }_{i}+\varepsilon_{i t},
\end{aligned}
$$

where $R_{i t}^{n}$ represents the ranking of trait $t, n$ is the number of traits in each cluster; Trait ${ }_{i t}$ is the binary variable representing trait $t$ for respondent $i$ (if trait $t$ is selected as most important, then for $R_{i t}=1$, Trait $_{i t}=1$, 0 otherwise; if trait $t$ is selected as second most important, then for $R_{i t}=2$, Trait $_{i t}=1$, 0 otherwise, and so on); Producer ${ }_{i}$ is the binary variable indicating whether the respondent is a producer; Years ${ }_{i}$ is the binary variable indicating whether the number of years of experience in the decision-making process of managing blueberry production is more than 10 (the average number of years in our sample of respondents); $\mathrm{Size}_{i}$ is the binary variable indicating whether the operation is $>16.2$ ha (B. Strik, personal communication, 16.2 ha is the average minimum operation size for a producer to send their product to a packinghouse; for operations $<16.2$ ha, production is typically sold by direct marketing); Newcultivar ${ }_{i}$ is the binary variable indicating whether a new cultivar has been planted in the last 5 years; Cultivar $_{i}$ is the binary variable for the cultivar with the largest acreage in the operation, $q(q=$ 'Duke', 'Bluecrop', 'Legacy', 'Aurora', etc.); and $\varepsilon_{i t}$ is the residual error term that is not captured by the explanatory variables, which is assumed to follow a normal distribution with mean 0 and SD $\sigma$.

Based on the state that respondents indicated as the location of the largest cultivated area (which was not necessarily the same state where the survey was distributed) responses were grouped into three regions. The Southeast included respondents with blueberry operations located in Georgia, Florida, North Carolina, Mississippi, Tennessee, and Alabama; the West included Oregon, Washington, and California, in the United States and British Columbia in Canada; and the Northeast and Midwest included New Jersey, Massachusetts, and Michigan. We combined responses from the Midwest and Northeast to ensure a sufficient number of observations because there were only 29 responses from the Midwest (Michigan). Because we conducted regressions for seven trait clusters (fruit quality, disease resistance, arthropod pest resistance, plant stress tolerance, machine harvestability, other plant traits, all trait clusters) and three regions ( $k=$ Midwest and Northeast, West, and Southeast), we present results for a total of $21(=7 \times$ 3) regressions. The model coefficients were estimated using PROC QLIM in SAS v.9.3 (SAS Institute, Cary, NC).

In each regression analysis, the variable "other trait" was set as the base variable. Hence, the statistical significance of traits should be interpreted as relative to the base variable. Because the most important trait was assigned a rank of 1 , the second most important was assigned 2, and so on; traits with significant negative coefficients were likely to be chosen as more important and traits with significant positive coefficients were likely to be chosen as less important compared with the "other trait" variable in each cluster. The magnitude of the coefficient estimates indicates the relative importance of the variable trait, higher values indicate higher relative importance compared with the base trait. Traits determined not to be statistically significant (i.e.,, not significantly different from the base trait) may still be considered of some importance to producers. The number of responses obtained from each region is different with 149 from the West, 155 from the Southeast, and 70 from the Midwest and Northeast. Arguably this difference in the number of responses would have an affect on the value of the coefficient estimates across regions. When presenting the coefficient estimates for all regressions, the McFadden likelihood ratio index (LRI) is included. This is a measure of goodness-of-fit that depicts the explanatory power of the model.

\section{Results and Discussion}

Summary statistics for producers by regions. We obtained 375 responses from 12 U.S. states and one Canadian province (Fig. 1). These regions account for over $99 \%$ of U.S. production, $98.6 \%$ of U.S. and Canada highbush production, and $93.7 \%$ of North American highbush blueberry production (Brazelton et al., 2017). The survey was conducted in nine states, but responses were recorded based on the state where the largest cultivated area of the respondent's blueberry operation was located. On average, $84 \%$ of respondents were producers, $9 \%$ were associated with packing houses, $6 \%$ with processing companies, $5 \%$ had other roles in the industry, $3 \%$ were associated with nurseries, $3 \%$ were nonbreeder researchers, and $1 \%$ were breeders. Note that these numbers do not add to $100 \%$ because some respondents marked more than one category. The average size of the blueberry operations was $46.1 \mathrm{ha}$. This size varied across regions, with the largest size in the Midwest and Northeast (54.8 ha), followed by the West (44.8 ha), and Southeast (43.0 ha) (Fig. 1). The average 
A

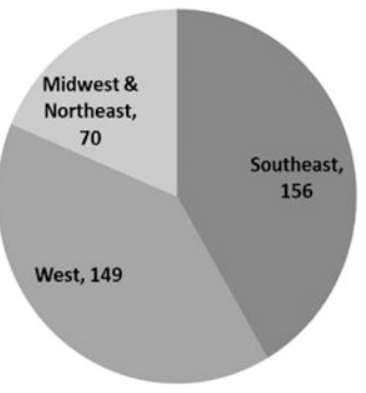

B

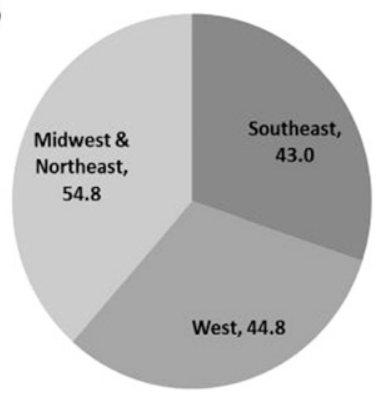

C

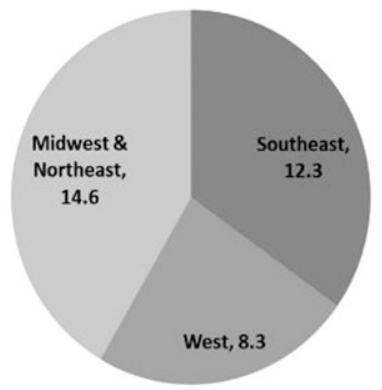

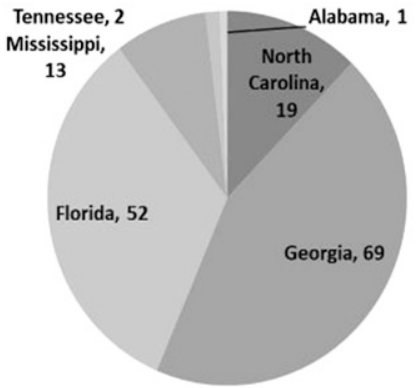

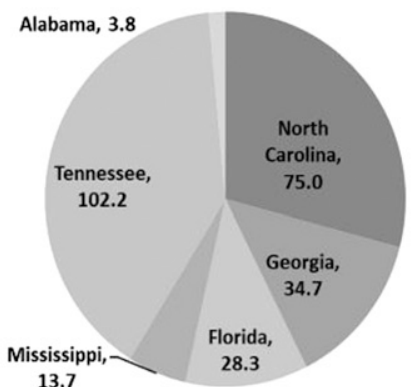

13.7

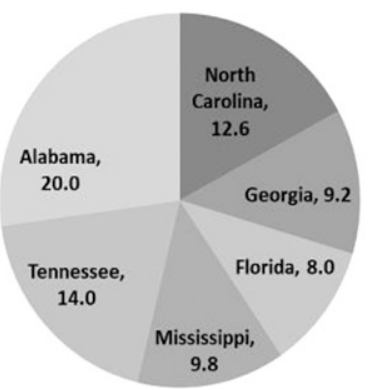

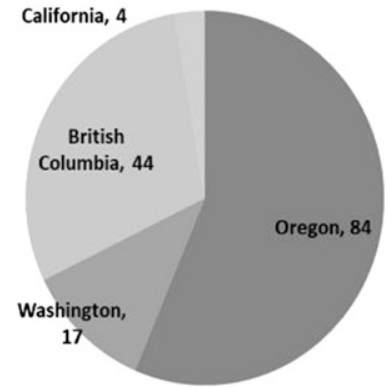
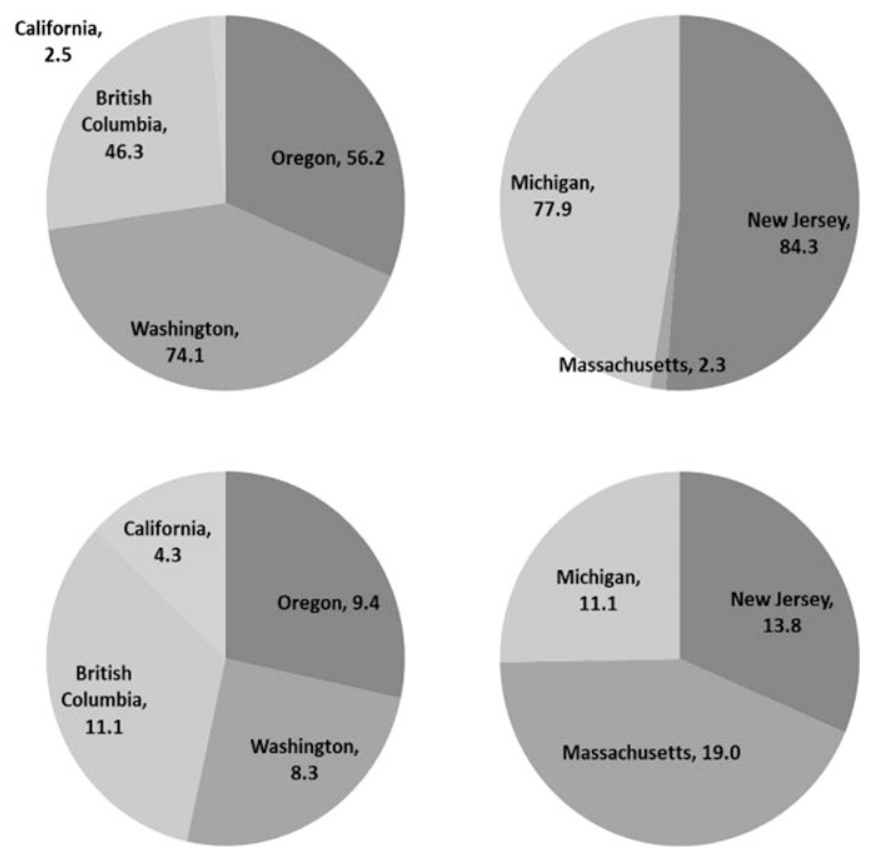

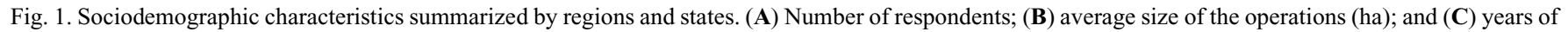
experience.

number of years involved in the decisionmaking process of blueberry operations was 10.3 years. Years of experience varied across regions, with the Midwest and Northeast averaging 14.6 years, the Southeast 12.3 years, and the West 8.3 years (Fig. 1).

Among the four cultivars with largest acreage currently growing in their fields, growers identified $30 \mathrm{NHB}, 8 \mathrm{RY}$ (V. virgatum), and 22 SHB cultivars (Supplemental Table 1). Overall, 'Duke' was the most predominant cultivar in production, followed by 'Bluecrop' and 'Emerald' (Supplemental Table 2). Interestingly, a comprehensive survey questionnaire on the blueberry industry of North America carried out in 1992 (Moore, 1993 ) included only two SHB cultivars. The larger number of important SHB cultivars included in our survey (22) is most likely a consequence of the rapid and more recent expansion of blueberry production into areas where low chilling conditions precluded their production in the past. Cultivars developed by breeders over the past 25 years underpinned this expansion (Lyrene, 2008). Of the seven most predominant replanted cultivars, on average, only $31 \%$ of the respondents replanted the same cultivar (Supplemental Table 3) suggesting that respondents are willing to take risks in hope of increasing investment returns by adopting different cultivars with improved characteristics.

Across all regions and all seven clusters of breeding traits (Tables 1-7), parameter estimates for the ordered probit model for the variables presented here (producer, years of experience, size of operation, whether new cultivars were planted, and the cultivars most planted) were not significant (data not shown), suggesting that differences are mainly explained by geographical regions and not biased by other factors.

Fruit and plant trait clusters. Parameter estimates for the ordered probit model differentiating results were different by region (Table 1). In the West and Southeast, fruit quality traits were the highest in importance among the clusters. In the Midwest and Northeast, disease resistance was the highest in importance, whereas fruit quality traits were the second highest. Disease resistance was the second highest in importance in the Southeast but less important in the West. Machine harvestability was the third highest in importance in the
Southeast but less important in the West and the least important in the Midwest and Northeast.

Across all regions, fruit quality had the highest probability of being ranked most important. Fruit quality traits are crucial for the best prices and ultimately profits obtained by producers. Because fresh fruit is generally sold at a much higher price than fruit for processing, $\$ 6.11$ vs. $\$ 1.56 / \mathrm{kg}$, respectively (U.S. Department of Agriculture, Economic Research Service, 2017), growers desire to allocate as much fruit as possible into the higher valued fresh market when possible. To meet the standards of the fresh market, it is critical to not only have cultivars that produce fruit with excellent shelf life but also essential to have excellent machine harvestability for the fruit to be the most profitable in the processed market. So although fruit firmness, harvestability, flavor, and size are crucial for fruit in both markets, their relative importance may vary (Brown et al., 1996; Padley, 2005). For instance, although a small, dry picking scar to avoid decay problems is essential for good shelf life in a fresh market berry, a berry that is frozen within hours of harvest does not have the same requirements. 
Similarly, fruit firmness is essential in both markets but for processing it is only essential for a berry to be harvested with no obvious external damage as it will be quickly processed whereas for the fresh market, fruit must have minimal internal bruising or other damage.

Fruit quality traits. Except for the Midwest and Northeast region, the three most important fruit quality traits were firmness, flavor, and shelf life (Table 2). Although the health benefits associated with blueberry consumption have been a main driving force for production and demand growth during the last 10-15 years (Forney and Kalt, 2011), this trait was ranked as the least important in the West and Southeast but among the more important in the Midwest and Northeast. We have no good explanations for this difference. However, no research has been carried out to study the genetic inheritance of fruit quality components directly associated with health benefits (e.g., antioxidant capacity, anthocyanin content) and link them to specific breeding traits. This observation could explain the overall lower level of importance signaled by stakeholders for this trait in our survey. It is interesting to compare priorities for fruit quality traits identifiedlargely by producers - in this study with consumer preferences examined previously by Gilbert et al. (2014). Consumers cited flavor and sweetness as positive and cited unpleasant textures such as mealy and pasty as negative characteristics. This was similar to the results in the present study where flavor was one of the most important fruit characteristics. Fruit firmness, which was appealing to the consumer as a component of fruit texture, is also important for hand or machine harvestability and shelf life (Moggia et al., 2017; Olmstead and Finn, 2014) and ranked as one of the most important traits. Flavor, size, and color are all part of the criteria used to determine grades and standards of blueberries and thus directly affect the price received by producers (U.S. Department of Agriculture, Agricultural Marketing Service, 1997).

Blueberries exhibit useful genetic variation for the most important fruit quality traits highlighted in this study (Hancock et al., 2008; Luby et al., 1991; Retamales and Hancock, 2012), suggesting opportunities to identify molecular markers associated with these traits that can be used to improve fruit characteristics that match consumer preferences and industry priorities. Indeed, several previous studies provided insights into the variability available in blueberry germplasm for fruit quality characteristics, including volatile compounds (Du et al., 2011; Farneti et al., 2017; Gilbert et al., 2015), flavor and taste (Gilbert et al., 2014; Saftner et al., 2008), chemical composition such as sugars and anthocyanin content (Gilbert et al., 2015; Silva et al., 2005; Yousef et al., 2014), texture (Ehlenfeldt and Martin, 2002; Giongo et al., 2013; Silva et al., 2005), shape and size (Parra et al., 2007). Fruit texture characteristics, such as firmness or crispness, have been

Table 1. Estimated ordered probit model coefficients for blueberry fruit quality and plant trait clusters and other variables based on a blueberry industry survey conducted in 2016 and 2017.

\begin{tabular}{|c|c|c|c|c|c|c|}
\hline \multirow[b]{2}{*}{ Variable } & \multicolumn{2}{|c|}{ West } & \multicolumn{2}{|c|}{ Midwest and Northeast } & \multicolumn{2}{|c|}{ Southeast } \\
\hline & $\overline{\text { Coefficient }}$ & SE & Coefficien & $\mathrm{SE}$ & Coefficient & SE \\
\hline Intercept & $1.119^{* * *}$ & 0.107 & $1.102^{* *}$ & 0.514 & $0.978^{* * *}$ & 0.164 \\
\hline Fruit quality traits & $-1.236^{* * *}$ & 0.100 & $-0.638^{*}$ & 0.350 & $-0.710 * * *$ & 0.105 \\
\hline Machine harvestability & -0.102 & 0.099 & $2.330^{* * *}$ & 0.401 & $-0.325^{* * *}$ & 0.113 \\
\hline Disease resistance & $0.264 * * *$ & 0.103 & $-1.155^{* * *}$ & 0.349 & $-0.390 * * *$ & 0.102 \\
\hline Arthropod resistance & $0.699 * * *$ & 0.102 & $-0.668^{*}$ & 0.362 & $0.755^{* * *}$ & 0.108 \\
\hline Plant stress tolerance & $1.002 * * *$ & 0.099 & $0.798^{*}$ & 0.420 & $0.891^{* * *}$ & 0.106 \\
\hline Number of observations & \multicolumn{2}{|c|}{702} & \multicolumn{2}{|c|}{60} & \multicolumn{2}{|l|}{600} \\
\hline Log likelihood & \multicolumn{2}{|c|}{$-1,131$} & \multicolumn{2}{|c|}{-84} & \multicolumn{2}{|c|}{-993} \\
\hline McFadden LRI & \multicolumn{2}{|c|}{0.130} & \multicolumn{2}{|c|}{0.257} & \multicolumn{2}{|c|}{0.077} \\
\hline
\end{tabular}

$*, * *, * *$ Significant at $P \leq 0.10,0.05$, and 0.01 , respectively.

Table 2. Estimated ordered probit model coefficients for blueberry fruit quality traits and other variables based on a blueberry industry survey conducted in 2016 and 2017.

\begin{tabular}{|c|c|c|c|c|c|c|}
\hline \multirow[b]{2}{*}{ Variable } & \multicolumn{2}{|c|}{ West } & \multicolumn{2}{|c|}{ Midwest and Northeast } & \multicolumn{2}{|c|}{ Southeast } \\
\hline & Coefficient & SE & Coefficient & SE & Coefficient & $\mathrm{SE}$ \\
\hline Intercept & $1.740 * * *$ & 0.084 & $1.415^{* * *}$ & 0.363 & $1.598^{* * *}$ & 0.123 \\
\hline Firmness & $-1.403 * * *$ & 0.107 & -0.494 & 0.375 & -1.290 *** & 0.115 \\
\hline Flavor & $-1.156^{* * *}$ & 0.104 & $-2.030 * * *$ & 0.459 & $-0.733 * * *$ & 0.112 \\
\hline Shelf life & $-0.604 * * *$ & 0.101 & -0.616 & 0.488 & $-0.596^{* * *}$ & 0.112 \\
\hline Size & $-0.308 * * *$ & 0.105 & 0.359 & 0.401 & 0.045 & 0.108 \\
\hline Shape/appearance & 0.042 & 0.103 & $1.544 * * *$ & 0.387 & $0.022 * * *$ & 0.111 \\
\hline Sweetness & $0.284 * * *$ & 0.105 & 0.037 & 0.381 & -0.038 & 0.113 \\
\hline Crispness & $0.190^{*}$ & 0.108 & $1.091^{* * *}$ & 0.361 & $0.478^{* * *}$ & 0.111 \\
\hline Nutritional benefit & $0.845^{* * *}$ & 0.104 & -0.085 & 0.429 & $0.467 * * *$ & 0.113 \\
\hline Small dry stem & $0.897 * * *$ & 0.105 & $1.740^{* * *}$ & 0.383 & $0.695 * * *$ & 0.111 \\
\hline Color & 0.087 & 0.104 & 0.130 & 0.393 & 0.166 & 0.111 \\
\hline Number of observations & \multicolumn{2}{|c|}{1,287} & \multicolumn{2}{|c|}{110} & \multicolumn{2}{|c|}{1,100} \\
\hline Log likelihood & \multirow{2}{*}{\multicolumn{2}{|c|}{$\begin{array}{c}-2,874 \\
0.069\end{array}$}} & \multirow{2}{*}{\multicolumn{2}{|c|}{$\begin{array}{l}-235 \\
0.109\end{array}$}} & \multirow{2}{*}{\multicolumn{2}{|c|}{$\begin{array}{r}-2,513 \\
0.047\end{array}$}} \\
\hline McFadden LRI & & & & & & \\
\hline
\end{tabular}

$*, * *, * *$ Significant at $P \leq 0.10,0.05$, and 0.01 , respectively.

Table 3. Estimated ordered probit model coefficients for blueberry disease resistance traits and other variables based on a blueberry industry survey conducted in 2016 and 2017.

\begin{tabular}{|c|c|c|c|c|c|c|}
\hline \multirow[b]{2}{*}{ Variable } & \multicolumn{2}{|c|}{ West } & \multicolumn{2}{|c|}{ Midwest and Northeast } & \multicolumn{2}{|c|}{ Southeast } \\
\hline & Coefficient & SE & Coefficient & SE & Coefficient & $\mathrm{SE}$ \\
\hline Intercept & $1.959^{* * *}$ & 0.067 & $2.043^{* * *}$ & 0.288 & $1.888^{* * *}$ & 0.096 \\
\hline Mummy berry & $-1.195 * * *$ & 0.105 & $-1.591 * * *$ & 0.382 & $-0.927 * * *$ & 0.110 \\
\hline Bot. flower blight \& fruit rot & $-0.975^{* * *}$ & 0.108 & $-0.881 * *$ & 0.379 & $-0.808^{* * *}$ & 0.114 \\
\hline Phytophthora root rot & $-0.823 * * *$ & 0.110 & $-1.136^{* *}$ & 0.495 & $-0.551 * * *$ & 0.123 \\
\hline Blueberry scorch virus & $-0.836 * * *$ & 0.114 & $-0.662 *$ & 0.341 & -0.125 & 0.143 \\
\hline Anthracnose fruit rot & $-0.781 * * *$ & 0.107 & $-0.786^{*}$ & 0.450 & $-0.637 * * *$ & 0.113 \\
\hline Blueberry shock virus & $-0.633 * * *$ & 0.105 & $0.972 * *$ & 0.397 & $0.728 * * *$ & 0.118 \\
\hline Alternaria fruit rot & $-0.719 * * *$ & 0.113 & -0.217 & 0.354 & 0.114 & 0.123 \\
\hline ght/canker & $-0.351 * * *$ & 0.108 & 0.570 & 0.765 & $0.267 * *$ & 0.135 \\
\hline Phomopsis twig blight & -0.048 & 0.124 & -0.339 & 0.336 & -0.012 & 0.123 \\
\hline Fungal leaf spots, rust & 0.185 & 0.121 & 0.118 & 0.413 & $-0.325^{* * *}$ & 0.110 \\
\hline Stem canker & $0.244 * *$ & 0.116 & 0.287 & 0.375 & $0.413^{* * *}$ & 0.117 \\
\hline Bacterial leaf scorch & $0.299 * *$ & 0.118 & -0.709 & 0.688 & $-0.544 * * *$ & 0.118 \\
\hline Stem & $0.475 * * *$ & 0.128 & -0.166 & 0.367 & $-0.579 * * *$ & 0.113 \\
\hline ing blotch virus & $0.595 * * *$ & 0.117 & 0.263 & 0.473 & $0.383 * * *$ & 0.130 \\
\hline Nematodes & $0.656 * * *$ & 0.114 & $1.913 * * *$ & 0.581 & $0.480 * * *$ & 0.111 \\
\hline Blueberry stunt & $0.668 * * *$ & 0.119 & $-1.065^{* *}$ & 0.496 & $0.427 * * *$ & 0.120 \\
\hline Exobasidium leaf and fruit spot & $0.866 * * *$ & 0.117 & 0.079 & 0.394 & $-0.589 * * *$ & 0.110 \\
\hline Algal stem blotch & $1.383 * * *$ & 0.109 & $1.334 * *$ & 0.557 & $1.041^{* * *}$ & 0.124 \\
\hline Number of observations & \multicolumn{2}{|c|}{2,223} & \multicolumn{2}{|c|}{190} & \multicolumn{2}{|c|}{1,900} \\
\hline Log likelihood & \multicolumn{2}{|c|}{$-6,223$} & \multicolumn{2}{|c|}{-532} & \multicolumn{2}{|c|}{$-5,400$} \\
\hline McFadden LRI & \multicolumn{2}{|c|}{0.049} & \multicolumn{2}{|c|}{0.050} & \multicolumn{2}{|c|}{0.035} \\
\hline
\end{tabular}

$*, * *, * *$ Significant at $P \leq 0.10,0.05$, and 0.01 , respectively.

associated with improved machine harvestability (Mehra et al., 2013; Olmstead and Finn, 2014), shelf life (Moggia et al., 2017), and consumer preferences (Gilbert et al., 2014).

Disease resistance. In all regions, resistance to mummy berry disease was the highest in importance (Table 3). Mummy berry is of economic concern in most areas of blueberry production from the southern United States to Canada and occurs in all species of cultivated blueberry (Scherm and Hildebrand, 2017). Because of the near-zero tolerance for mummified fruit in commercial blueberry shipments, most losses associated with the disease are due to the rejection or 
downgrading of affected fruit loads in the packinghouse. In line with our results, a producer survey in Georgia in 1999 ranked mummy berry as the most important blueberry disease, considered a "major" problem by more than $75 \%$ of the participating blueberry producers (Scherm et al., 2001). Differences in environmental conditions across regions can influence the specific types of diseases and potential disease vectors (Hancock et al., 2008). For example, in the Midwest and Northeast, resistance to Blueberry stunt appeared to be more important than in the West and Southeast.

Arthropod resistance. In all regions, resistance to SWD was the most important trait among the list of arthropod resistance traits (Table 4). SWD is a relatively new pest (first detected in 2008 in the United States) that adapts to a wide range of environmental conditions and is very damaging because of its high reproduction capability (Goodhue et al., 2011; Quarles, 2015). Although comprehensive research efforts have been undertaken to prevent and treat SWD infestations (Asplen et al., 2015; Burrack, 2016), no formal studies have been conducted to identify blueberry fruit characteristics or accessions resistant to SWD that could help manage this pest and reduce the risk of crop losses.

Similar to disease resistance, prevalence of arthropod activity is influenced by environmental conditions, hence, the relative importance of other arthropod pest species differed across regions. For example, resistance to winter moth was second in importance after SWD in the Midwest and Northeast but not considered as important in the West and Southeast.

Abiotic stress tolerance. Results for traits in this cluster differed across regions (Table 5). In the West, tolerance to heat/ ultraviolet damage was selected as the most important abiotic stress, whereas in the Southeast tolerance to frost was most important. In the Midwest and Northeast, no specific abiotic stress tolerance was significantly more important, but heat tolerance was significantly less important. The higher level of heat tolerance identified in southern highbush (SHB) cultivars (Lobos and Hancock, 2015) may explain the fact that this trait did not rank high in importance in the Southeast. No formal studies have been conducted to identify genetic factors controlling ultraviolet/heat tolerance, drought tolerance, or frost tolerance in blueberry but genetic variation, different levels of heritability, and large environmental effects have been documented (Hancock et al., 2008).

Other plant traits. In all regions, improved plant yield was selected as the most important other plant trait (Table 6). Acceptable yield is critical for profitability, although producers may accept lower yields if they are being paid a premium for fruit quality or for having fruit available in a specific ripening season. Genetics, production environment, and plant management (fertilization, irrigation, pruning, frequency of harvest, use and type of pollinators and planting design) affect

Table 4. Estimated ordered probit model coefficients for blueberry arthropod pest resistance traits and other variables based on a blueberry industry survey conducted in 2016 and 2017.

\begin{tabular}{|c|c|c|c|c|c|c|}
\hline \multirow[b]{2}{*}{ Variable } & \multicolumn{2}{|c|}{ West } & \multicolumn{2}{|c|}{ Midwest and Northeast } & \multicolumn{2}{|c|}{ Southeast } \\
\hline & Coefficient & SE & Coefficient & SE & Coefficient & SE \\
\hline Intercept & $2.097 * * *$ & 0.078 & $2.355 * * *$ & 0.325 & $2.139 * * *$ & 0.106 \\
\hline $\mathrm{SWD}^{\mathrm{z}}$ & $-2.250 * * *$ & 0.117 & $-2.042 * * *$ & 0.389 & $-2.069 * * *$ & 0.118 \\
\hline Aphids & $-0.828 * * *$ & 0.099 & $-1.319 * * *$ & 0.376 & $0.198^{*}$ & 0.113 \\
\hline $\mathrm{BMSB}^{\mathrm{y}}$ & $-0.628 * * *$ & 0.103 & $0.696^{*}$ & 0.395 & $0.349 * * *$ & 0.115 \\
\hline Blueberry maggot & $-0.432 * * *$ & 0.112 & $-1.042 * * *$ & 0.384 & $-1.020 * * *$ & 0.109 \\
\hline Gall midge & $-0.189^{*}$ & 0.114 & 0.486 & 0.366 & $-0.901 * * *$ & 0.107 \\
\hline Scale insects & -0.134 & 0.107 & -0.158 & 0.401 & $-0.204 *$ & 0.113 \\
\hline White grubs & -0.027 & 0.109 & $0.928 * * *$ & 0.353 & $0.520 * * *$ & 0.118 \\
\hline Cherry fruit worm & 0.080 & 0.113 & -0.156 & 0.378 & $0.266^{* *}$ & 0.125 \\
\hline Stem borers & -0.157 & 0.116 & 0.275 & 0.372 & 0.083 & 0.120 \\
\hline Bud mite & $0.217^{*}$ & 0.113 & 0.194 & 0.402 & $-0.364 * * *$ & 0.111 \\
\hline Flower thrips & 0.120 & 0.111 & 0.558 & 0.406 & $-0.698 * * *$ & 0.111 \\
\hline Winter moth & $0.255 * *$ & 0.102 & $-1.731 * * *$ & 0.365 & $0.913 * * *$ & 0.116 \\
\hline Sharp-nosed leafhopper & $0.272 * *$ & 0.118 & 0.194 & 0.391 & $-0.368 * * *$ & 0.121 \\
\hline Stem gall wasp & $0.239 * *$ & 0.110 & 0.278 & 0.374 & $0.446 * * *$ & 0.117 \\
\hline Cranberry fruit worm & $0.523 * * *$ & 0.122 & $-0.606^{*}$ & 0.336 & $0.207^{*}$ & 0.119 \\
\hline Plum curculio & $0.658 * * *$ & 0.116 & 0.303 & 0.399 & 0.161 & 0.121 \\
\hline Number of observations & \multicolumn{2}{|c|}{1,989} & \multicolumn{2}{|c|}{170} & \multicolumn{2}{|c|}{1,700} \\
\hline Log likelihood & \multicolumn{2}{|c|}{$-5,348$} & \multicolumn{2}{|c|}{-445} & \multicolumn{2}{|c|}{$-4,515$} \\
\hline McFadden LRI & \multicolumn{2}{|c|}{0.051} & \multicolumn{2}{|c|}{0.076} & \multicolumn{2}{|c|}{0.063} \\
\hline
\end{tabular}

$*, * *, * * *$ Significant at $P \leq 0.10,0.05$, and 0.01 , respectively.

${ }^{\mathrm{z}} \mathrm{SWD}=$ spotted wing drosophila.

${ }^{\mathrm{y}} \mathrm{BMSB}=$ brown marmorated stink bug.

Table 5. Estimated ordered probit model coefficients for blueberry abiotic stress tolerance traits and other variables based on a blueberry industry survey conducted in 2016 and 2017.

\begin{tabular}{|c|c|c|c|c|c|c|}
\hline \multirow[b]{2}{*}{ Variable } & \multicolumn{2}{|l|}{ West } & \multicolumn{2}{|c|}{ Midwest and Northeast } & \multicolumn{2}{|c|}{ Southeast } \\
\hline & Coefficient & SE & Coefficient & SE & Coefficient & SE \\
\hline Intercept & $0.910 * * *$ & 0.114 & $0.956 * *$ & 0.475 & $1.105 * * *$ & 0.170 \\
\hline Heat tolerance/ultraviolet damage & $-0.662 * * *$ & 0.116 & $1.271 * * *$ & 0.399 & $0.217^{*}$ & 0.120 \\
\hline Frost tolerance & 0.009 & 0.113 & 0.055 & 0.365 & $-0.993 * * *$ & 0.132 \\
\hline Soil type adaptation & $0.434 * * *$ & 0.116 & 0.002 & 0.363 & $0.276^{* *}$ & 0.122 \\
\hline Winterhardiness & $0.448 * * *$ & 0.113 & -0.260 & 0.368 & $0.268 * *$ & 0.121 \\
\hline Drought resistance & $0.578 * * *$ & 0.117 & -0.457 & 0.361 & -0.091 & 0.085 \\
\hline Number of observations & \multicolumn{2}{|l|}{702} & \multicolumn{2}{|l|}{60} & \multicolumn{2}{|l|}{600} \\
\hline Log likelihood & \multicolumn{2}{|c|}{$-1,207$} & \multicolumn{2}{|l|}{-101} & \multicolumn{2}{|l|}{$-1,029$} \\
\hline McFadden LRI & \multicolumn{2}{|c|}{0.040} & \multicolumn{2}{|l|}{0.060} & \multicolumn{2}{|l|}{0.043} \\
\hline
\end{tabular}

$*, * *, * * *$ Significant at $P \leq 0.10,0.05$, and 0.01 , respectively.

Table 6. Estimated ordered probit model coefficients of other blueberry plant traits and other variables based on a blueberry industry survey conducted in 2016 and 2017.

\begin{tabular}{|c|c|c|c|c|c|c|}
\hline \multirow[b]{2}{*}{ Variable } & \multicolumn{2}{|c|}{ West } & \multicolumn{2}{|c|}{ Midwest and Northeast } & \multicolumn{2}{|c|}{ Southeast } \\
\hline & Coefficient & SE & Coefficient & SE & Coefficient & SE \\
\hline Intercept & $1.247 * * *$ & 0.138 & $1.192^{* *}$ & 0.553 & $1.242 * * *$ & 0.196 \\
\hline Yield & $-1.28 * * *$ & 0.137 & $-1.105 * *$ & 0.438 & $-1.059 * * *$ & 0.143 \\
\hline \multirow[t]{2}{*}{ Ripening time } & $-0.828 * * *$ & 0.131 & -0.040 & 0.384 & $-0.630 * * *$ & 0.140 \\
\hline & $0.666 * * *$ & 0.130 & -0.410 & 0.403 & $0.400 * * *$ & 0.137 \\
\hline Flowering time & $0.822 * * *$ & 0.132 & $0.702 *$ & 0.413 & -0.071 & 0.138 \\
\hline Number of observations & \multicolumn{2}{|l|}{585} & \multicolumn{2}{|c|}{50} & \multicolumn{2}{|c|}{500} \\
\hline Log likelihood & \multicolumn{2}{|c|}{-804} & \multicolumn{2}{|c|}{-74} & \multicolumn{2}{|c|}{-754} \\
\hline McFadden LRI & \multicolumn{2}{|c|}{0.147} & \multicolumn{2}{|c|}{0.080} & \multicolumn{2}{|c|}{0.063} \\
\hline
\end{tabular}

$*, * *, * * *$ Significant at $P \leq 0.10,0.05$, and 0.01 , respectively.

yield levels. Although attempts have been made to estimate yield indirectly (Hancock et al., 2000), fruit must be harvested and weighed to determine yield accurately; this is feasible in more advanced selection stages of breeding but cannot be used as a selection tool in seedlings where mostly subjective evaluations are used.

Machine harvestability. Fruit firmness and uniform ripening were the two most important traits included among machine harvestability traits (Table 7). Overall, these results confirm that fruit firmness is a critical trait in blueberry because it can contribute to increase profitability by increasing price premiums and reducing labor costs needed to harvest the fruit. Implementing mechanical harvesting for the fresh market is crucial to the long-term sustainability of the blueberry industry in times when harvest labor pools are decreasing and competition from regions worldwide with much lower picking costs is intensifying (Rodgers et al., 2017). The challenge when using machines to harvest blueberries is fruit bruising and associated lowering of fruit quality and shelf life. Fruit firmness is a general term to indicate fruit that are resistant or more tolerant to compression 
Table 7. Estimated ordered probit model coefficients for blueberry machine harvestability traits and other variables based on a blueberry industry survey conducted in 2016 and 2017.

\begin{tabular}{|c|c|c|c|c|c|c|}
\hline \multirow[b]{2}{*}{ Variable } & \multicolumn{2}{|c|}{ West } & \multicolumn{2}{|c|}{ Midwest and Northeast } & \multicolumn{2}{|c|}{ Southeast } \\
\hline & Coefficient & SE & Coefficient & SE & $\overline{\text { Coefficient }}$ & SE \\
\hline Intercept & $1.924^{* * *}$ & 0.101 & $1.479 * * *$ & 0.387 & $1.749^{* * *}$ & 0.142 \\
\hline Fruit firmness & $-1.963 * * *$ & 0.119 & $-1.708 * * *$ & 0.612 & $-1.837 * * *$ & 0.128 \\
\hline Uniform ripening & $-1.498 * * *$ & 0.115 & $-1.381 * * *$ & 0.494 & $-0.894 * * *$ & 0.116 \\
\hline Upright growth & $-0.455 * * *$ & 0.111 & -0.885 & 0.744 & $-0.351 * * *$ & 0.114 \\
\hline Loose clusters & -0.062 & 0.111 & $1.304 *$ & 0.679 & $-0.383 * * *$ & 0.111 \\
\hline Narrow habit & $0.205^{*}$ & 0.110 & $0.961 *$ & 0.557 & $0.606^{* * *}$ & 0.113 \\
\hline Small dry stem scar & $0.720 * * *$ & 0.113 & $1.254 * *$ & 0.577 & $0.566^{* * *}$ & 0.113 \\
\hline Monopodial stem & $0.736 * * *$ & 0.114 & $1.117 * *$ & 0.568 & $0.403^{* * *}$ & 0.114 \\
\hline Flexible canes & $0.776^{* * *}$ & 0.112 & -0.689 & 0.593 & $0.300 * * *$ & 0.111 \\
\hline Number of observations & \multicolumn{2}{|c|}{1,054} & \multicolumn{2}{|c|}{90} & \multicolumn{2}{|c|}{900} \\
\hline Log likelihood & \multicolumn{2}{|c|}{$-2,040$} & \multicolumn{2}{|c|}{-185} & \multicolumn{2}{|c|}{$-1,804$} \\
\hline McFadden LRI & \multicolumn{2}{|c|}{0.119} & \multicolumn{2}{|c|}{0.064} & \multicolumn{2}{|c|}{0.088} \\
\hline
\end{tabular}

$*, * *, * * *$ Significant at $P \leq 0.10,0.05$, and 0.01 , respectively.

forces, which ultimately reduces fruit bruising during harvest and sorting. Breeders typically use this trait to select cultivars adapted to mechanical harvesting (Mehra et al., 2013; Moggia et al., 2017, Olmstead and Finn, 2014). Firmness has largely been evaluated subjectively by simply squeezing the fruit and objectively by using the compression force method (Jiang et al., 2016) and, as mentioned previously, has also been associated with consumer preference and extended shelf life. Despite the relevance of this trait in the blueberry production and distribution chain, it is still unclear which specific fruit texture characteristics - such as crispness, hardness, juiciness, and mealinessare most critical for overall firmness and extended shelf life, consumer preference, and resistance to bruising. Alternative highthroughput methods based on bioyield force (Blaker et al., 2014) and near-infrared hyperspectral reflectance imaging (Jiang et al., 2016) have been developed to evaluate fruit damage. Mechanical force methods such as the texture analyzer have been used to study fruit texture characteristics associated with extended shelf life, but this method has not been correlated with resistance to mechanical fruit damage (Giongo et al., 2013). Integrating these methods into large-scale studies represents an opportunity to improve the understanding of which texture component(s) contribute to resistance to bruising and to extended shelf life, and the genetic mechanism(s) controlling these traits.

Harvesting time is a critical factor for adopting machine harvest systems because producers often seek to maximize the volume of fruit harvested in the high-value price windows (Olmstead and Finn, 2014). This has often resulted in selection for very early or late maturity, largely without consideration of how concentrated the ripening period may be. However, uniform ripening is critical to maximize machine harvest efficiency by avoiding losses associated with removing an excessive amount of green fruit or harvesting too many overripe fruits (Olmstead and Finn, 2014). Uniform ripening is equally important for efficient hand harvesting. Although genetic variation for ripening interval has been described in blueberry germplasm, no standardized high-throughput method has been developed to phenotype uniform ripening, hampering large-scale genetic studies.

\section{Conclusions}

This study is the first effort to identify the most important fruit and plant breeding traits from representatives of the highbush blueberry industry in the major growing areas in the United States and Canada. The importance of various plant and fruit traits was prioritized to determine the traits that must be present in new cultivars in order for the industry to adopt them and to be considered successful in the marketplace. Industry responses, in general, signaled that the most important trait cluster was fruit quality, particularly firmness, flavor, and shelf life. These fruit quality traits can affect producer price premiums, positively drive consumer demand, and improve machine harvestability, all of which are critical to the economic viability of the commercial production.

Disease resistance generally ranked the second most important trait cluster. There were regional differences in the importance assigned to traits influenced by differences in production environment, such as disease resistance, arthropod resistance, and tolerance to abiotic stress. With respect to arthropod pests, SWD was overwhelmingly perceived as the major arthropod threat to the industry's sustainability. For other plant traits, yield was consistently selected as most important. Survey responses also showed that producers replanting a field are willing to adopt newer cultivars with perceived advantages over currently grown cultivars.

Results from this study will be useful to academia, government, and industry groups working to enhance the economic profitability of the blueberry industry. These results provide clues about where investment in research and development should focus to address challenges affecting the industry.

\section{Literature Cited}

Alpuerto, V.E., G.W. Norton, J. Alwang, and A.M. Ismail. 2009. Economic impact analysis of marker-assisted breeding for tolerance to salinity and phosphorous deficiency in rice. Rev. Agr. Econ. 31:779-792.

Asplen, M.K., G. Anfora, A. Biondi, D. Choi, D. Chu, K.M. Daane, P. Gibert, A.P. Gutierrez, K.A Hoelmer, W.D. Hutchison, R. Isaacs, Z.L. Jiang, Z. Kárpáti, M.T. Kimura, M. Pascual, C.R. Philips, C. Plantamp, L. Ponti, G. Vétek, H. Vogt, V.M. Walton, Y. Yu, L. Zappala, and N. Desneux. 2015. Invasion biology of spotted wing drosophila (Drosophila suzukii): A global perspective and future priorities. J. Pest Sci. 88:469-494.

Blaker, K.M., A. Plotto, E.A. Baldwin, and J.W. Olmstead. 2014. Correlation between sensory and instrumental measurements of standards and crisp-texture southern highbush blueberries (Vaccinium corymbosum L. interspecific hybrids). J. Sci. Food Agr. 94: 2785-2793

Brazelton, C., K. Young, and N. Bauer. 2017. 2016 global blueberry statistics and intelligence report. Intl. Blueberry Organization (IBO). 3 Sept. 2017. <http://www.internationalblueberry.org/>.

Brown, G.K., N.L. Schulte, E.J. Timm, R.M. Beaudry, D.L. Peterson, J.F. Hancock, and F. Takeda. 1996. Estimates of mechanization effects on fresh blueberry quality. Appl. Eng. Agr. 12:21-26.

Burrack, H.J. 2016. Sustainable strategies to manage spotted wind drosophila in United States food crops. Current Res. Info. System (CRIS). 7 Dec. 2017. <http://cris.nifa.usda.gov/cgi-bin/ starfinder/0?path $=$ fastlink $1 . t x t \& i d=$ anon\&pass $=$ $\&$ search $=\mathrm{R}=68624 \&$ format $=$ WEBLINK $>$.

Davis, C.G. and J.M. Gillespie. 2004. What role does specialization play in farm size in the U.S. hog industry? Southern Agr. Economics Assn. Annu. Mtg., Tulsa, OK.

Du, X., A. Plotto, M. Song, J. Olmstead, and R. Rouseff. 2011. Volatile composition of four southern highbush blueberry cultivars and effect of growing location and harvest date. J. Agr. Chem. 59:8347-8357.

Ehlenfeldt, M.K. and R.B. Martin, Jr. 2002. A survey of fruit firmness in highbush blueberry and species-introgressed blueberry cultivars. HortScience 37:386-389.

Farneti, B., I. Khomenko, M. Grisenti, M. Ajelli, E. Betta, A.A. Algarra, L. Cappellin, E. Aprea, F. Gasperi, F. Biasioli, and L. Giongo. 2017. Exploring blueberry aroma complexity by chromatographic and direct-injection spectrometric techniques. Front. Plant Sci. 8:617

Forney, C.F. and W. Kalt. 2011. Blueberry and cranberry, p. 51-73. In: L.A. Terry (ed.). Health-promoting properties of fruit and vegetables. CABI, Wallingford, UK.

Gallardo, R.K., D. Nguyen, V. McCracken, C. Yue, J. Luby, and J. McFerson. 2012. An investigation of trait prioritization in rosaceous fruit breeding programs. HortScience 47: 771-776.

Gilbert, J.L., M.J. Guthart, S.A. Gezan, M.P. de Carvalho, M.L. Schwieterman, T.A. Colquhoun, L.M. Bartoshuk, C.A. Sims, D.G. Clark, and J.W. Olmstead. 2015. Identifying breeding priorities for blueberry flavor biochemical, sensory and genotype by environment analyses. PLoS One 10:e138494.

Gilbert, J.L., J.W. Olmstead, T.A. Colquhoun, L.A. Levin, D.G. Clark, and H.R. Moskowitz. 2014. Consumer-assisted selection of blueberry fruit quality traits. HortScience 49:864-873.

Giongo, L., P. Poncetta, P. Loretti, and F. Costa. 2013. Texture profiling of blueberries ( Vaccinium spp.) during fruit development, ripening and storage. Postharvest Biol. Technol. 76: 34-39. 
Goodhue, R.E., M. Bolda, D. Farnsworth, J.C. Williams, and F.G. Zalom. 2011. Spotted wing drosophila infestation of California strawberries and raspberries: Economic analysis of potential revenue losses and control costs. Pest Mgt. Sci. 67:1396-1402.

Greene, W.H. and D.A. Hensher. 2008. Modeling ordered choices: A primer and recent developments. Working paper, New York Univ.

Hancock, J.F., P. Callow, R.I. Keesler, D. Prince, and B. Bordelon. 2000. A crop estimation technique for highbush blueberries. J. Amer. Pomol. Soc. 54:123-129.

Hancock, J.F., P. Lyrene, C.E. Finn, N. Vorsa, and G.A. Lobos. 2008. Blueberries and cranberries, p. 115-150. In: J.F. Hancock (ed.). Temperate fruit crop breeding: Germplasm to genomics. Springer, New York, NY.

Jiang, Y., C. Li, and F. Takeda. 2016. Nondestructive detection and quantification of blueberry bruising using near-infrared (NIR) hyperspectral reflectance imaging. Scientific Rpt. 6:35679.

Lancaster, K.J. 1966. A new approach to consumer behavior theory. J. of Political Economy 74:132-157.

Lobos, G.A. and J.F. Hancock. 2015. Breeding blueberries for a changing global environment: A review. Front. Plant Sci. 6:782.

Luby, J.J., J.R. Ballington, A.D. Draper, K. Pliszka, and M.E. Austin. 1991. Blueberries and cranberries (Vaccinium). Genetic resources of temperate fruit and nut crops. Acta Hort. 290:391-456.

Luby, J.J. and D.V. Shaw. 2001. Does markerassisted selection make dollars and sense in a fruit breeding program? HortScience 36:872879.

Lyrene, P. 2008. Breeding southern highbush blueberries. Plant Breeding Rev. 30:353-414.

Mehra, L.K., D.D. MacLean, A.T. Savelle, and H. Scherm. 2013. Postharvest disease development on southern highbush blueberry fruit in relation to berry flesh type and harvest method. Plant Dis. 97:213-221.

Moggia, C., J. Graell, I. Lara, G. González, and G.A. Lobos. 2017. Firmness at harvest impacts postharvest fruit softening and internal browning development in mechanically damaged and non-damaged highbush blueberries (Vaccinium corymbosum L.). Front. Plant Sci. 8:535.

Moore, J.N. 1993. Blueberry cultivars of North America. HortTechnology 3:370-374.

Olmstead, J.W. and C.E. Finn. 2014. Breeding highbush blueberry cultivars adapted to machine harvest for the fresh market. HortTechnology 24:290-294.

Padley, L., Jr. 2005. Firmness and storage characteristics of crisp-textured blueberries. Master's Diss., Univ. Florida. 30 Dec. 2017. <http:// ufdcimages.uflib.ufl.edu/UF/E0/01/21/82/ 00001/padley_l.pdf>.

Parra, R., Z.D. Lifante, and B. Valdés. 2007. Fruit size and picking scar size in some blueberry commercial cultivars and hybrid plants grown in SW Spain. Intl. J. Food Sci. Technol. 42:880-886.

Quarles, W. 2015. IPM for spotted wing drosophila. IPM Pract. 35:1-7.

Retamales, J.B. and J.F. Hancock. 2012. Blueberry taxonomy and breeding, p. 19-50. In: J.B. Retamales and J.F. Hancock (eds.). Blueberries. CABI, Cambridge, MA.

Rodgers, A., K.L. Morgan, and A. Harri. 2017. Technology adoption and risk preferences: The case of machine harvesting by southeastern blueberry producers. J. Food Distrib. Res. 48:1-21.

Saftner, R., J. Polashock, M. Ehlenfeldt, and B. Vinyard. 2008. Instrumental and sensory quality characteristics of blueberry fruit from twelve cultivars. Postharvest Biol. Technol. 49:19-26.

Scherm, H. and P.D. Hildebrand. 2017. Mummy berry, p. 30-32. In: Compendium of blueberry, cranberry, and lingonberry diseases and pests. 2nd ed. APS Press, St. Paul, MN.

Scherm, H., D.S. Nesmith, D.L. Horton, and G. Krewer. 2001. A survey of horticultural and pest management practices of the Georgia blueberry industry. Small Fruits Rev. 1:17-28.

Silva, J.L., E. Marroquin, F.B. Matta, J.O. Garner, Jr., and J. Stojanovic. 2005. Physicochemical, carbohydrate and sensory characteristics of highbush and rabbiteye blueberry cultivars. J. Sci. Food Agr. 85:1815-1821.

Sullivan, K.P. and B.J. Schilling. 2008. The economic impact of New Jersey's blueberry and cranberry industries. Rutgers Univ., New Jersey Agr. Expt. Sta., New Brunswick, NJ. 7 Dec. 2017. <http://ora.rutgers.edu/docs/2010_Econ_ Imp_NJ_Cranberry_Blueberry.pdf $>$.

Takeda, F., G. Krewer, E.L. Andrews, B. Mullinix, Jr., and D.L. Peterson. 2008. Assessment of the V45 blueberry harvester on rabbiteye blueberry and southern highbush blueberry pruned to V-shaped canopy. HortTechnology $1: 130-138$.

U.N. Food and Agriculture Organization. 2017. Crop production data. 7 Dec. 2017. <http:// www.fao.org/faostat/en/\#home>.

U.S. Department of Agriculture, Agricultural Marketing Service. 1997. United States standards for grades of blueberries. U.S. Dept. Agr., Washington, D.C. 7 Dec. 2017. <https://www. ams.usda.gov/sites/default/files/media/Blueberries_Standard\%5B1\%5D.pdf $>$.

U.S. Department of Agriculture, Economic Research Service. 2017. Noncitrus fruits and nuts 2016 summary. U.S. Dept. Agr., Washington, D.C. 7 Dec. 2017. <http://usda.mannlib.cornell.edu/MannUsda/viewDocumentInfo.do? documentID $=1113>$.

Yang, H., C. Li, H-M. Lam, J. Clements, G. Yan, and S. Zhao. 2015. Sequencing consolidates molecular markers with plant breeding practice. Theor. Appl. Genet. 128:779-795.

Yousef, G.G., M.A. Lila, I. Guzman, J.R. Ballington, and A.F. Brown. 2014. Impact of interspecific hybridization on anthocyanin profile of southern highbush blueberry. J. Amer. Soc. Hort. Sci. 139:99-112.

Yue, C., R.K. Gallardo, J. Luby, A. Rihn, J.R. McFerson, V. McCracken, D. Bedford, S. Brown, K. Evans, C. Weebadde, A. Sebolt, and A.F. Iezzoni. 2013. An investigation of United States apple producers' trait prioritization-Evidence from audience surveys. HortScience 48:13781384.

Yue, C., R.K. Gallardo, V.A. McCracken, J. Luby, J.R. McFerson, L. Liu, and A. Iezzoni. 2012. Technical and socio-economic challenges to setting and implementing priorities in North American rosaceous fruit breeding programs. HortScience 47:1320-1327. 
Supplemental Table 1. List of predominant blueberry cultivars in production.

\begin{tabular}{|c|c|c|c|c|c|c|c|c|}
\hline No. & Cultivar name & Type & No. & Cultivar name & Type & No. & Cultivar name & Type \\
\hline 1 & Aurora & $\mathrm{NHB}^{\mathrm{z}}$ & 1 & Alapaha & $\mathrm{RY}^{\mathrm{y}}$ & 1 & Abundance & $\mathrm{SHB}^{\mathrm{x}}$ \\
\hline 2 & Berkeley & NHB & 2 & Austin & RY & 2 & Chickadee & SHB \\
\hline 3 & Bluecrop & NHB & 3 & Brightwell & RY & 3 & Emerald & SHB \\
\hline 4 & Bluejay & NHB & 4 & Climax & RY & 4 & Farthing & SHB \\
\hline 5 & Blueray & NHB & 5 & Premier & RY & 5 & Flicker & SHB \\
\hline 6 & Blue Ribbon & NHB & 6 & Tifblue & RY & 6 & Georgia Dawn & SHB \\
\hline 7 & Bluetta & NHB & 7 & Titan & RY & 7 & Jewel & SHB \\
\hline 8 & Cargo & NHB & 8 & Vernon & RY & 8 & Kestrel & SHB \\
\hline 9 & Chandler & NHB & & & & 9 & Meadowlark & SHB \\
\hline 10 & Croatan & NHB & & & & 10 & New Hanover & SHB \\
\hline 11 & Darrow & NHB & & & & 11 & O’Neal & SHB \\
\hline 12 & Draper & NHB & & & & 12 & Paloma & SHB \\
\hline 13 & Duke & NHB & & & & 13 & Rebel & SHB \\
\hline 14 & Earliblue & NHB & & & & 14 & San Joaquin & SHB \\
\hline 15 & Elizabeth & NHB & & & & 15 & Scintilla & SHB \\
\hline 16 & Elliott & NHB & & & & 16 & Southern Belle & SHB \\
\hline 17 & Hardyblue (1613A) & NHB & & & & 17 & Springhigh & SHB \\
\hline 18 & Jersey & NHB & & & & 18 & Springwide & SHB \\
\hline 19 & Last Call & NHB & & & & 19 & Star & SHB \\
\hline 20 & Lateblue & NHB & & & & 20 & Suziblue & SHB \\
\hline 21 & Legacy & $\mathrm{NHB}^{\mathrm{w}}$ & & & & 21 & Sweetcrisp & SHB \\
\hline 22 & Liberty & NHB & & & & 22 & Windsor & SHB \\
\hline 23 & Northland & NHB & & & & & & \\
\hline 24 & Olympia & NHB & & & & & & \\
\hline 25 & Patriot & NHB & & & & & & \\
\hline 26 & Reka & NHB & & & & & & \\
\hline 27 & Sierra & $\mathrm{NHB}^{\mathrm{w}}$ & & & & & & \\
\hline 28 & Spartan & NHB & & & & & & \\
\hline 29 & Top Shelf & NHB & & & & & & \\
\hline 30 & Weymouth & NHB & & & & & & \\
\hline
\end{tabular}

${ }_{\mathrm{z}} \mathrm{NHB}=$ northern highbush blueberry.

${ }^{\mathrm{y}} \mathrm{RY}=$ rabbiteye.

${ }^{\mathrm{x}} \mathrm{SHB}=$ southern highbush blueberry.

${ }^{\mathrm{w}}$ Although a SHB by pedigree, behaves like NHB in regards to chilling.

Supplemental Table 2. Number of respondents indicating which cultivars represented the largest acreage in their operation and which cultivars were planted in the last 5 years with the largest acreage based on a blueberry industry survey conducted in 2016 and 2017.

\begin{tabular}{|c|c|c|c|c|c|c|c|c|c|c|c|c|c|c|c|}
\hline & \multicolumn{15}{|c|}{ Current cultivars being planted with the largest acreage, No. responses } \\
\hline & Duke & Bluecrop & Farthing & Legacy & Draper & Liberty & Rebel & Emerald & Star & Brightwell & Jersey & Premier & Aurora & Jewel & Elliott \\
\hline West & 62 & 12 & 0 & 10 & 7 & 7 & 0 & 0 & 0 & 0 & 0 & 1 & 8 & 0 & 1 \\
\hline Midwest & 0 & 9 & 0 & 0 & 1 & 1 & 1 & 0 & 0 & 0 & 10 & 0 & 0 & 0 & 4 \\
\hline Northeast & 13 & 12 & 0 & 0 & 0 & 0 & 0 & 0 & 0 & 0 & 7 & 0 & 0 & 0 & 2 \\
\hline Southeast & 0 & 1 & 15 & 4 & 0 & 0 & 3 & 28 & 22 & 20 & 0 & 9 & 0 & 8 & 0 \\
\hline \multirow[t]{3}{*}{ Total } & 75 & 34 & 15 & 14 & 8 & 8 & 4 & 28 & 22 & 20 & 17 & 10 & 8 & 8 & 7 \\
\hline & \multicolumn{15}{|c|}{ Newly planted cultivars with the largest acreage, number of responses } \\
\hline & \multicolumn{3}{|c|}{ Bluecrop } & Farthing & \multicolumn{2}{|c|}{ Legacy } & aper & Liberty & \multicolumn{2}{|c|}{ Rebel } & & & & & \\
\hline West & \multicolumn{3}{|l|}{14} & 0 & \multicolumn{2}{|c|}{7} & 11 & 10 & \multicolumn{2}{|c|}{0} & & & & & \\
\hline Midwest & \multicolumn{3}{|c|}{2} & 0 & \multicolumn{2}{|l|}{0} & 0 & 1 & \multicolumn{2}{|c|}{0} & & & & & \\
\hline Northeast & 5 & \multicolumn{2}{|c|}{3} & 0 & \multicolumn{2}{|l|}{0} & 8 & 1 & \multicolumn{2}{|c|}{1} & & & & & \\
\hline Southeast & 0 & \multicolumn{2}{|c|}{0} & 22 & \multicolumn{2}{|l|}{6} & 2 & 0 & \multicolumn{2}{|c|}{6} & & & & & \\
\hline Total & 20 & \multicolumn{2}{|c|}{6} & 22 & 13 & & 21 & 12 & \multicolumn{2}{|c|}{7} & & & & & \\
\hline
\end{tabular}

Supplemental Table 3. Replanting distribution of current blueberry cultivars with new cultivars based on a industry survey conducted in 2016 and 2017.

\begin{tabular}{lrcccccc}
\hline & \multicolumn{7}{c}{ Newly planted cultivar } \\
\cline { 2 - 7 } & Duke & Bluecrop & Farthing & Legacy & Draper & Liberty & Rebel \\
\cline { 2 - 7 } Current cultivar & 17 & 0 & 0 & 0 & 17 & 7 & 0 \\
\hline Duke $(N=75)$ & 6 & 15 & 0 & 3 & 9 & 6 & 0 \\
Bluecrop $(N=34)$ & 0 & 0 & 53 & 0 & 0 & 0 & 7 \\
Farthing $(N=15)$ & 21 & 0 & 0 & 50 & 0 & 0 & 0 \\
Legacy $(N=14)$ & 25 & 0 & 0 & 0 & 38 & 0 & 0 \\
Draper $(N=8)$ & 0 & 0 & 0 & 0 & 13 & 25 & 0 \\
Liberty $(N=8)$ & 0 & 0 & 0 & 0 & 0 & 0 & 0 \\
Rebel $(N=4)$ & & & & & & 0 & 0 \\
\hline
\end{tabular}

